\title{
The relevance of various subject areas taught in business strategy. The use of multidimensional scaling to map managers' perceptions
}

\author{
P.A. Miller \\ IESE, University of Navarra, Barcelona
}

\author{
A. H. Money \\ Graduate School of Business, University of Cape Town, Rondebosch
}

The research outlined had as primary objective the testing of managers' perceptions of those areas taught in the business policy programmes. A significant finding is the cognitive linking of strategy and structure without prior exposure to the literature or concepts. Among top managers this linking was related to resource orientation, a conclusion previously held by Bower (1970). The perceptual positioning of a political orientation suggests that the emphasis given to intra-organizational political strategies is of little relevance to managers who prefer organizations without a political atmosphere. Finally the 'fire-fighting' aspect which often makes the case-study method pedagogically exciting is questioned, because the aspect is closely related to the functional duties of executives rather than the strategic nature of the executive function. 'Firefighting' problems are per se short-term and are radically different to strategic problems which require a broader long-term view.

S. Afr. Bus. Mgmt. 1984, 15: $162-168$

Die navorsing is gedoen met die basiese oogmerk om bestuurders se siening van besigheidsbeleidsprogramme, soos tans aangebied, te toets. 'n Belangrike bevinding is die kognitiewe skakeling van strategie met struktuur, sonder voorafgaande blootstelling aan die literatuur en konsepte. Topbestuurders het hierdie skakeling verbind aan hulpbron. orientasie, soos voorheen deur Bower (1970) voorgestaan. Intraorganisatoriese politiek was van min betekenis vir diegene wat 'n organisasie met 'n politiek-vrye atmosfeer verkies het. Verder het die sogenaamde 'brandslaan'-(fire-fighting) aspek van die gevallestudiemetode nie veel byval gevind nie: Dit is verbind aan die uitvoerende amptenaar se funksie, eerder as aan strategiese bestuursfunksies. 'Brandslaan'-probleme is van korttermyn-aard en verskil radikaal van strategiese probleme wat 'n langtermyn-benadering verg.

S.-Afr. Tydskr. Bedryfsl. 1984, 15: $162-168$

\section{P.A. Miller}

IESE, University of Navarra, Avenida Pearson 21, Barcelona, Spain

\author{
A. H. Money* \\ Graduate School of Business, University of Cape Town, Private Bag, \\ Rondebosch 7700, Republic of South Africa \\ -To whom correspondence should be addressed
}

\section{Introduction}

The primary objective of this article is to establish the perceptions of managers who have attended or are attending programmes at a business school with respect to organizational structure in business policy/strategy courses.

Questionnaires were distributed to participants already attending executive programmes at a business school and their responses with regard to business policy/strategy programmes were subjected to multidimensional scaling procedures to develop perceptual maps, in an attempt to evaluate their perceptions of the various areas covered in such programmes.

Hence described below is the first step towards achieving the above objective. The sub-objectives are:

(i) To establish suitable dimensions for deriving a realistic perceptual map based on areas covered in business policy programmes without unduly biasing respondents.

(ii) To test the usefulness of multidimensional scaling techniques for this type of research. Multidimensional scaling has never been applied under these circumstances and the uniqueness of the application in itself could raise certain methodological questions. There has been a suggestion that the technique has a place in policy research by Hatten 'perceptual mapping (multidimensional scaling) should allow us to explore managers' views of corporate or personal success. It would be possible to design a survey . . . across hierarchies and across companies ' (Hatten, 1979: 465).

\section{Creation of dimensions}

The plethora of concepts that have been advocated under the title of business policy/strategy do not always fit conveniently into simplified categories. So, for example, the Boston Consulting Group matrix could be regarded as a functional technique (a view held by many marketing lecturers) or alternatively a strategic general management tool (as advocated by many business strategists). Aranoff (1975) resorts to using Heyel's 'Encyclopedia of Management' (Heyel, 1973) to determine the categories of the behaviourial sciences covered in management science textbooks. This approach was rejected because of the broad spread of categories in the area that could not possibly be included in a questionnaire. (Furthermore Heyel avoids the area of business policy in his Encyclopedia, possibly for this very reason).

The need to disguise the areas appeared to be an important aspect, as researchers did not want respondents to guess what responses would be considered appropriate. An intrinsic element (and an assumption) of the methodology, is that the 
researcher does not approach the problem of perceptual mapping with 'preconceived notions of what should be done according to the normative dictates of our theory' (Hatten, 1979:465), but instead works backwards from the very judgements that managers themselves make. From this a theory is developed. It was thus decided to focus on the concepts of management tasks. The reasons for this are that the activity of business policy involves management tasks and judgements about tasks. 'Judgement is an expression of preference and is based on perceptions of independence, dominance, indifference and likeness' (Hatten, 1979:465). If managers are asked about their particular tasks one could determine the emphasis placed on areas such as organization design. So the questionnaire would not be on what managers had learnt on business policy programmes but on what they were doing in the 'real world', this being the practising of business policy. While categorization now became easier it was decided that prescriptive texts would not be used to determine categories. The idea of managers planning, organizing, coordinating, implementing, and so on is one largely postulated by prescriptive texts. There appears to be sufficient empirical evidence to suggest that what managers do is very different (Stewart, 1967; Mintzberg, 1973). Kotter addresses this problem and believes that management theories need to be overhauled and established on a sounder footing. 'One of the key reasons why recent observational work on managerial behaviour and more traditional management theories have been difficult to reconcile is that they tend to focus (implicitly) on behaviour in different time frames. The newer work deals with daily behaviour, the more traditional work with behaviour in much longer time frames' (Kotter, 1982:148). The prescriptive texts appear to have addressed this longer time frame and to most managers this would appear remote. The shorter time frame, being more realistic to managers, would therefore provide the vehicle for this disguised questionnaire.

As a starting point a five-category classification was adopted based on Kotter's six key challenges and dilemmas. Only one key challenge was not used because, as a task, it remained somewhat ambiguous. Key problem/challenge \# 4 'Getting the information, cooperation and support needed from bosses to do the job. Being demanding with superiors without being perceived as uncooperative' (Kotter, 1982:148), seemed too intangible to categorize as a management task. Furthermore all the remaining key challenges encompassed in broad terms most of the areas taught in business policy programmes.

It was felt that the terminology used by Kotter needed only slight alteration to serve the purposes of this research. Where he speaks of key challenges/problems this was changed to 'orientation'. In addition his numerical classification was replaced with a 'keyword' classification. So that his Key problem/challenge \# 1 'Setting basic goals, policies and strategies despite great uncertainties' was altered to read:

- Strategic orientation. Those aspects concerning the determination of plans, goals or objectives, mission or purpose, policies, targets, strengths and weaknesses, and numerous other aspects.

The remainder were developed as follows:

- Resource orientation. Those aspects revolving around resource audits and allocation issues as determined by functional and business needs.

- Problem-solving orientation. Those aspects and skills concerning 'fire-fighting' in an organization. This being one of the implicit objectives of many business policy programmes.
- Network orientation. Those aspects involved in getting corporate staff, other relevant departments or divisions, and important external groups to cooperate despite lack of formal authority over them.

- Subordinate orientation. Those aspects involving the provision of visible leadership, the motivation of subordinates, and the controlling of a work force.

However these categories did not include any specific mention of the organizational structure element of business policy programmes, so a further category was added:

- Structural orientation. Those aspects involving the determination of the most suitable organization design for the implementation of strategies. These include issues of centralization or decentralization of structure and systems, span of control, hierarchical design, organization charts, divisionalization, and so on.

Implicit in the above is that the manager also has certain functional skills. Having chosen a particular career path, he would have specialized in one or two functional areas. Depending on the level of the manager, this area may still take a major part of his working day. Therefore the seventh orientation was outlined as:

- Functional orientation. Those aspects which would be termed specifically functional as opposed to 'general management' areas. For example, marketing, finance, production, with specific tasks being performed within those functions. Marketing, for example, would include functions such as advertising, market research, retailing, and so on.

There appeared to be one further area not explicitly defined. Highlighted by Kotter in Key challenge \#4 and others, this involved politicking within the organization - an area which often conjures up negative connotations. Pfeffer defines this negative quality as 'the Law of Political Entropy' (Pfeffer, 1981:32). However a more positive definition offered by the same author is 'organization politics involves those activities taken within organizations to acquire and use, power and other resources, to obtain one's preferred outcomes in a situation in which there is uncertainty or dissensus (sic.) about choices' (Pfeffer, 1981:32). The eighth orientation was simply defined as:

- Political orientation. Those aspects concerned with politicking within the organization.

When compared with other lists of managers' tasks this one is both brief and yet comprehensive. The researchers believe that the terminology would be easier to understand than that used by say Mintzberg (1973) whose tasks need elaborate description or alternatively Stewart, whose definitions, though aimed at managers, tend to be extremely vague and imprecise (Stewart, 1979:66 - 75). One might justifiably argue that the approach is too simplistic and at the same time, that the judgements made in these areas can never be mapped. Obviously they are complex. Steinbruner's (1974) description of how the most complex set of decisions are simplified and structured according to an already-established set of beliefs and values is of relevance here. He postulated that given situations similar to the ones being faced by this sample of managers in terms of diuturnity (of long duration) of complexity, the decision-maker will achieve psychological congruence by simplifying his perceptions. It would seem therefore that managers would match their perceptions with a simplified structure of beliefs and values and these perceptions should be fairly easy to map. 


\section{Hypotheses}

Having defined the eight categories to be used as the dimensions in the research, the following hypotheses were postulated:

(i) Functional orientation aspects are closely aligned to the Strategic orientation as perceived by managers.

(ii) Problem-solving orientation aspects will tend to be related to Strategic orientation in the minds of managers.

(iii) Resource orientation aspects are closely related to Functional orientation.

(iv) Structural orientation will tend to be related to Subordinate and Network orientation.

\section{Multidimensional scaling (MDS)}

A person's decision processes usually reflect the blending of a complex pattern and number of stimuli. MDS procedures assume that respondents' judgements are multifaceted; with the assistance of computer algorithms a geometric representation of the respondents' perceptions (perceptual map) for a specified number of dimensions can be constructed from simple input data. The data can be the respondents' overall judgements of the relative similarity among stimuli and/or in the form of rank orders of preference among them. The researcher starts with a unidimensional input-data set, usually a rank ordering and then uses a nonmetric multidimensional-scaling algorithm to construct from this single-dimensioned input-data set a perceptual map for the specified number of dimensions.

In this section, the method is outlined. The data are gathered in two steps. In the first step each manager is confronted with a list of eight orientations which he is asked to rank on the basis of those which are 'most-closely related' to those which are 'least-closely related'. The eight orientations are briefly defined though how they may be related is not discussed with the selected sample. (See Appendix) The orientations are listed in Table 1.

Table 1 Orientations to be
ranked by managers on the
basis of most-closely related
to least-closely related
1. Strategic orientation
2. Resource orientation
3. Problem-solving orientation
4. Network orientation
5. Subordinate orientation
6. Structural orientation
7. Functional orientation
8. Political orientation

The mechanics of this ranking process are simple but fairly tedious. Each manager is presented with 28 pairs of orientations, being the maximum number of combinations possible given eight categories. These pairs are printed on chits which are handed to all participants (see Appendix). Each participant must then rank all pairs from those that are most-closely related to those that are least-closely related. It is suggested in the briefing and in the covering handout that the easiest way to start a ranking process is to start with three obvious classifications; (i) those that are obviously related, (ii) those that are obviously unrelated, and (iii) those that fall between (i) and (ii). It then becomes an easy task to rank within each category and finally to combine three categories with adjustments to marginal cases. At no time is the term 'related' defined.

These similarity judgements were processed using the INDSCAL procedure originated by Carroll \& Chang (Green \& Rao, 1972:65 - 68), so as to establish the positions of the eight orientations on the dimensions. In the second step the manager indicated his preference with regard to the eight categories, in terms of his perception of the ideal manager, his own selfesteem, success in his present job and importance in his career as a whole (see Appendix). Using the PREFMAP (Green \& Rao, 1972:65 - 68) procedure these preferences, represented by vectors, were then overlayed on the previously obtained map to construct the so-called joint space configuration. It was felt that these were all fairly similar; certain rankings might differ slightly, which in turn would provide a vector 'band' across the configuration rather than a single line. This subsequently proved correct. However it appeared as if an ideal vector would have been as effective a guide as the 'band'.

\section{The study}

The initial design of the questionnaire having been based on orientations of management, it consisted of a three-page description of the method and the definitions used in the research (see Appendix). As can be seen the research was disguised as being a management-style questionnaire as most of the definitions fell in that broad area. Also one of the researchers had already covered this subject with the respondents some two days before. All respondents were attending a Programme for Management Development at the University of Cape Town's Graduate School of Business.

The researchers distributed the questionnaires together with a stack of 28 chits showing the possible combination of orientations (see Appendix). The 103 delegates were introduced to the technique, the objectives of the research, and the easiest method of completing the questionnaire. Questions from the group were answered and delegates were given some 20 hours in which to return the completed combinations and ideal ratings. During that evening any further problems were handled as the researchers made contact with each delegate individually. (During this time all delegates were meeting in their group syndicates.)

All questionnaires were returned by $08 \mathrm{~h} 30$ the following morning and processed over a period of two days using the PREFMAP and INDSCAL procedures. Ten per cent of the returns were rejected because of incorrect completion.

The results of this manipulation are shown in Figures 1 and 2. Owing to the nature of the programme there were no managers who were at a lower management level. This meant that perceptual maps for only top and middle managers were created. These maps showed interesting similarities as well as differences.

Both groups of managers perceived political orientation to be on the outer extremities of the map. It was seen as being unrelated to any other orientation. This view may support Kotter's observations that the general manager's process of network creation involves the minimization of politics (Kotter, 1982:148).

As noted before the definition of axes is probably one of the most critical aspects of MDS interpretation. The horizontal axis was defined as 'positional orientation'. Thompson (1967) has postulated that the managerial function is a maintenance of a balance between positional and strategic considerations. The positional considerations require a 'co-alignment of technology and task environment with a viable domain (Thompson, 1967). He also concluded that a key function of 


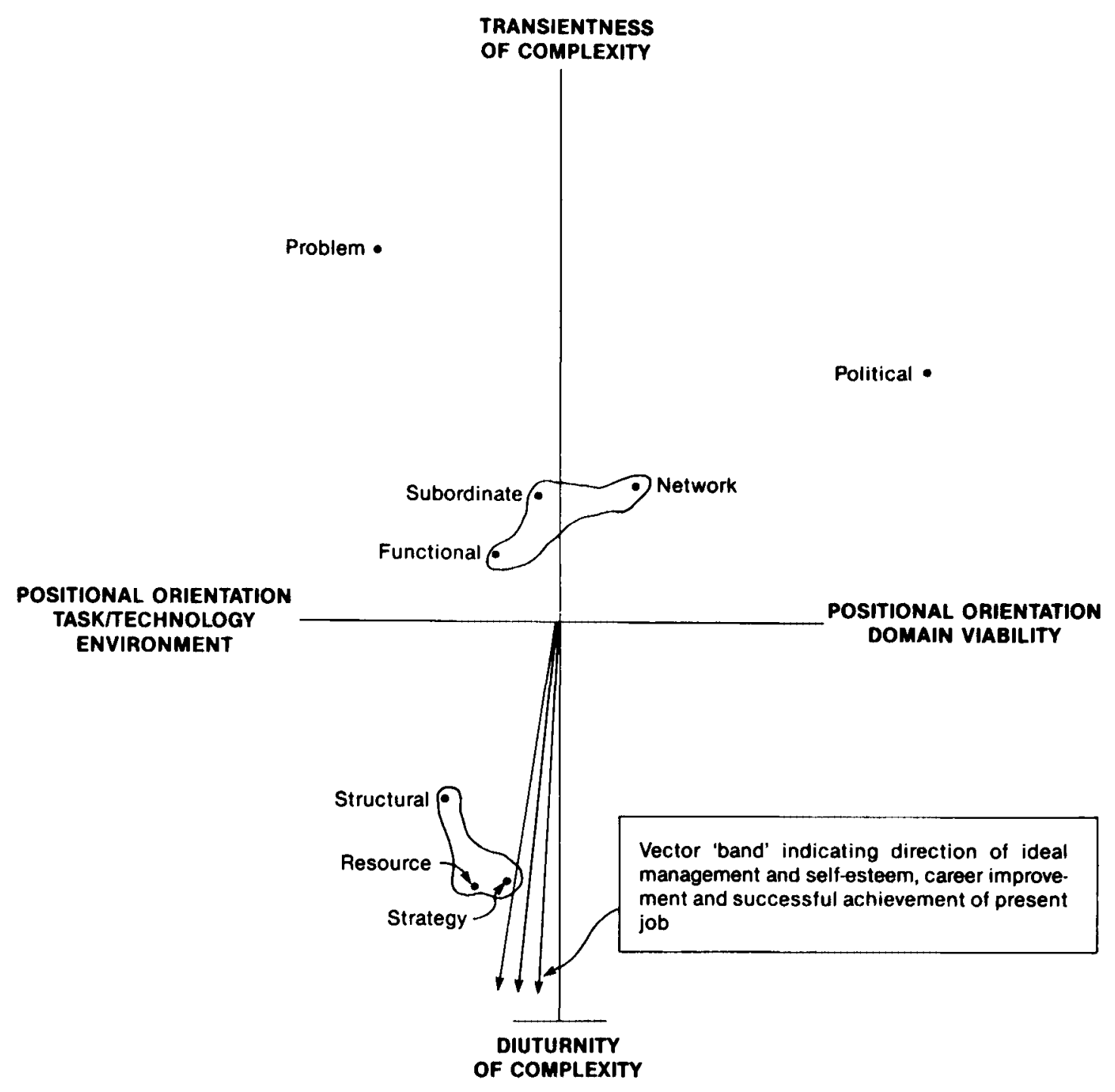

Figure 1 Pilot study: Perceptual map for senior managers

management is to maintain the organization at the nexus of several streams of actions. Clearly those actions are as perceived by managers themselves. The horizontal axis therefore ranges from Task/Technology environment to Domain viability. So for example, concerted and overt Political orientation may provide increased domain viability but in the process may alienate subordinates thereby making problem solving more difficult.

The vertical axis is defined in the time-frame context mentioned above that Kotter has referred to. Many authors, including Ansoff (1978), have attempted to develop models that incorporate unpredictable turbulence requiring flexible 'firefighting' skills. Essentially these skills would seem to be clustered at the short-term end of a continuum ranging from short to long term. However this is not a true reflection of the nature of turbulence, since it will have an influence on strategic thinking in the long term as well. This influence may not be as clearly delineated as in the short term but adds further to the complexity of determining long-term strategies. In the short term turbulence is identified and dealt with. The apparent complexity of the decision process is reduced by the transience (Steinbruner, 1974).

On the other hand in the long term the level of complexity would appear to be increased by the extended time frame. The nature of decision making itself becomes more complex in trying to deal with greater levels of ambiguity (Chandler, 1962:400). The label used in this case is on a scale of Diutur- nity of Complexity to the Transientness of Complexity.

Significant in this study is the linking of strategy and structure by a group, few of whom would have been exposed to either the literature or the classical arguments surrounding the strategy-structure debate. (On this PMD these issues were raised only after the completion of the research.) This linking is easily discernible in both perceptual maps. The difference between the positioning within the maps is attributable to top managers relating resource orientation to strategy and structure. In other words the long-term orientation of top managers involves all three aspects of strategy, structure, and resource orientation. Whereas middle managers whose jobs would normally be more resource orientated than strategically or structurally orientated clearly separate these issues. Top managers also see this clustering as being more task/technologically orientated than middle managers who see only resource orientation in this sense strategic and structural orientations are still somewhat remote to them and therefore related to domain viability and political orientation.

Both groups linked network, functional, and subordinate orientations. However as is to be expected the positioning of these clusters indicates differing perspectives. Top managers saw the cluster as being as task/technology orientated as that of the strategy-structure-resource clustering, though being of a short-term nature with reduced complexity. Middle managers saw the clustering as being more task/technology orientated 


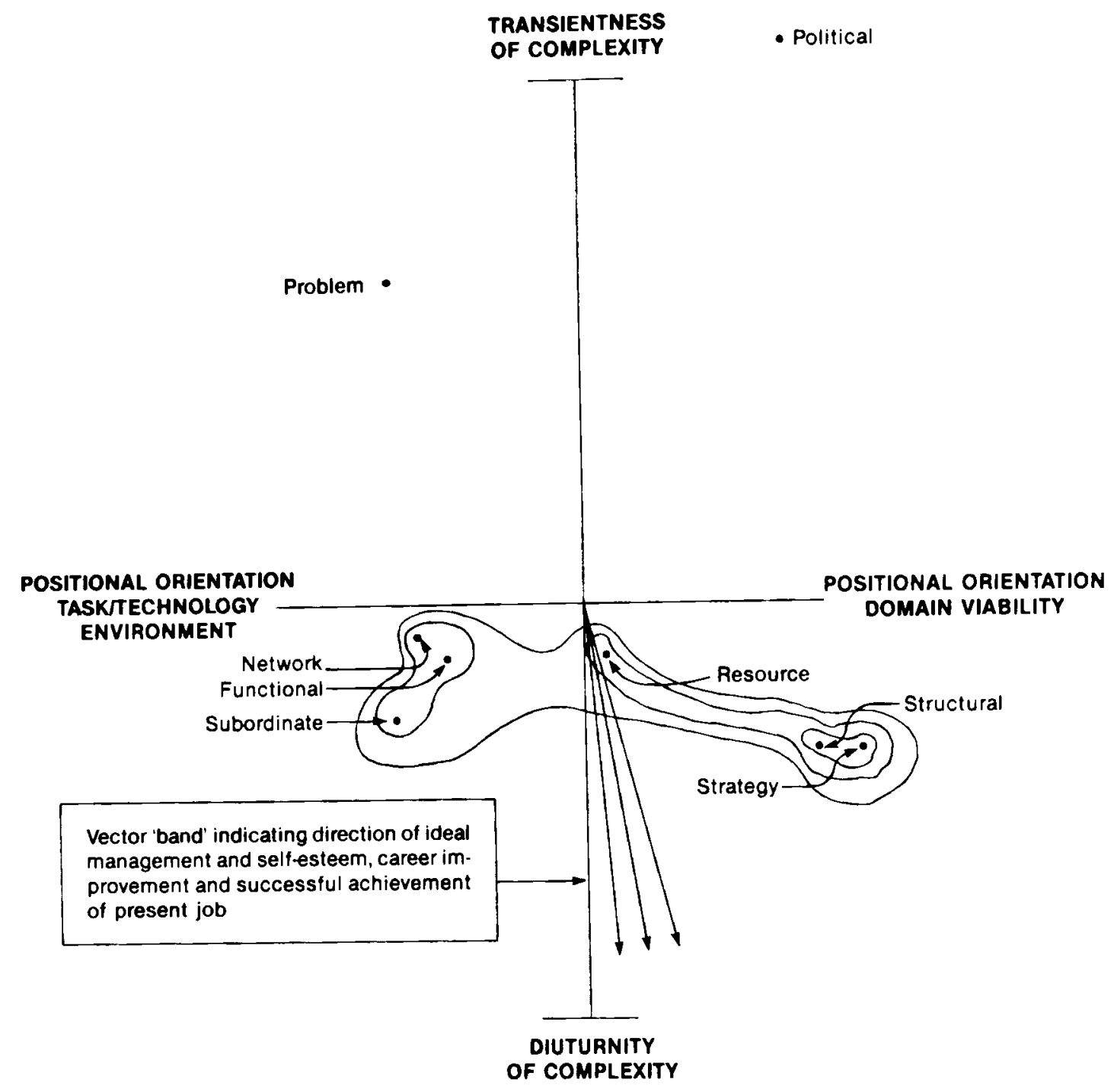

Figure 2 Pilot study: Perceptual map for middle managers

than resource orientation or the strategy-structure clustering and as long term and complex as the latter.

An examination of the problem-solving orientation may help to explain the above phenomenon. Problem-solving orientation is seen by both groups as task/technology orientated and of transient complexity; its positioning by both groups is very similar. The problems of middle managers would be more related to subordinate motivation, functional issues, and network development while top managers would have problems related to similar issues but together with the strategy-structureresource issues.

The positioning of vectors as shown in Figures 1 and 2 indicate the differing perspectives. The vectors form a band, the distance along which measures the significance of each orientation. In this case because all vectors move from top to bottom, the positioning of the perpendicular, from a point of the orientation to the vector on a scale from top to bottom, would indicate the relative importance of each orientation in ascendiing order. In the case of top managers the strategy-structureresource cluster followed by functional, subordinate, network, problem-solving, and political orientations form the order of importance. The order for middle managers is similar except the cluster of resource, functional, subordinate, and network is almost indiscernible from that of strategy and structure.

\section{Interpretation}

The findings of this research have implications in three prin- cipal areas:

- The strategy-structure-resource issues,

- the political environment of the organization, and

- the problem-solving approach to management education and, in particular, business policy.

The strategy-structure debate is largely polarized along the lines of those who support the theory and those who do not. Those who do have searched for a predictable sequence of phenomena with limited success. This study would appear to be the first that successfully demonstrated the link between strategy and structure in the minds of managers. Though Chandler and others have suggested that the link may only be after the fact, that the link did not consciously exist because 'administrators were too involved in day-to-day tactical activities to appreciate or understand the longer-range organizational needs of their enterprises, or else their training and education failed to sharpen their perception of organizational problems or failed to develop their ability to handle them (Chandler, 1962:400), this result demonstrates that these managers perceive a clear linkage between strategy and structure. Rumelt's idea that multi-divisionalization has insulated 'a set of business managers from the vicissitudes of the capital markets, and has created a type of managerial environment that encourages rapid re-deployment of resources and places a premium on economic performance and the skills of the generalist (Rumelt, 1974:2), seems to be borne out by his finding. General managers can no longer be 'too involved' in daily operations to ignore the 
importance of effective structures. While the problem of precendence cannot be answered from these results, the implication for the teaching of business policy is that there appears to be a need for a fair coverage of organization-design factors in business policy programmes.

So too the linking of resource orientation with strategystructural orientation provides further evidence for Bower's view of the strategic importance of resource allocation. 'It is precisely these relationships of structure to strategy that help to provide a prescription for the integrating phases of resource allocation. It is the responsibility of these managers performing the task of "man in the middle" to use their understanding of the qualitative elements of product-market strategic considerations to evaluate long-range programs in a way that will ensure consistency between the initial definitions by productmarket sub-units and the objectives of the corporate whole along the multiple dimensions of strategy' (Bower, 1970:288). What to Bower is a prescriptive model, is to these managers a perceived 'real-world' integrated relationship between strategy-structure-resource allocation.

The emphasis that has been placed in recent years on politics in organizations, reveals an area that these managers seem to want to reject. They find political orientation to be excessively domain orientated almost to the extent of being negatively task related. Furthermore this particular orientation is seen as transient as problem-solving orientation. Yet many of them may have to get involved in politics though they find is distasteful. Politically free organizations may seem to be happier and as a result healthier organizations to work in. An active attempt to reduce political in-fighting would seem to be more positive a step than actually taking part in political activity.

Finally the traditional case-study method tends to require the student to solve problems, essentially to fight fires. As can be seen problem solving is associated with functional duties and is particularly transient in complexity. The core issues of strategy-structure-resource allocation may not be problematic in a fire-fighting sense. Instead they call for greater conceptual skills. One may hypothesize that the student needs to approach these core issues with a broader longer-term view, radically different to the 'define the problem, alternatives, and solution' approach. The competitor analysis tack, while being very popular for its structured approach, does not necessarily engender the type of skills needed to guide an organization in the long term.

\section{Limitations}

Though the results of the study were encouraging certain aspects were of concern:

(i) The method of returning the stack of combinations increased the possibility of either an error occurring during the sorting of the paper chits by the respondent, or a datacollection error being made, as the computer operators had to physically handle every chit, of which there were 2996.

(ii) The use of keywords to identify definitions made the respondents' tasks much easier but the researcher feared that the keyword itself carried certain preconceptions. For example, the term 'strategic' has certain evocative nuances to anyone who has read widely in the area of management. Furthermore the concept of an 'orientation' as opposed to a 'task' seemed ambiguous.

(iii) The lack of lower management on the course has left a gap in the research.

The above research may suffer from two further important limitations. Firstly, the problem of substantiation, common to most MDS methods, exists here as well. While the researcher has labelled the axes on a temporal basis of complexity and 'positional orientation' (these appearing to have the most suitable fit), they are still subjective and readers might find a more appropriate fit.

Secondly, as pointed out by Green \& Tull (1975:633), 'at a deeper conceptual level many fundamental problems still exist regarding the meanings of such terms as "similarity" and "preference" and their sensitivity to environmental context.' In this research the terms 'most-closely related' and 'leastclosely related' were used without giving respondents guidance as to the criteria for closeness of relationships. This turns out to be both a weakness and a strength. A weakness because of each respondent using his own criteria, which could lead to vastly different perceptual maps for each respondent. The resulting interpretation would be rendered meaningless. A strength because, as in this case, respondents' maps correspond closely, thereby providing firm data for interpretation.

\section{References}

Ansoff, H.I. 1978. Planned management of turbulent change. Encyclopedia of professional management. New York: McGraw-Hill.

Aranoff, C. 1975. The rise of the behavioural perspective in selected general management textbooks. Acad. Manage. J., vol. 18 , $753-767$

Bower, J.L. 1970. Managing the Resource Allocation process. Humewood: Richard D. Irwin, 288

Chandler, A.D. 1962. Sirategy and structure. New York: Doubleday $\&$ Co., 400 .

Green, P. \& Rao, V. 1972. Configuration synthesis in MDS. J. Mark. Res, vol. 9, 65-68.

Green, P. \& Tull, D.S. 1975. Research for marketing decisions. Englewood Cliffs: Prentice-Hall, 633.

Hatten, K.J. 1979. Quantitative research methods in strategic management. In: Strategic management, (ed.) Schendel, D.E. \& Hofer C.W., Boston: Little, Brown \& Company, 465.

Heyel, C. 1973. The encyclopedia of management. New York: Reinhold.

Kotter, J. 1982. The general managers. New York: The Free Press, 148 .

Mintzberg, H. 1967. The nature of managerial work. New York: Harper and Row.

Pfeffer, J. 1981. Power in organisations. Massachusetts: Pitman Publishing Inc., 32.

Rumelt, R, 1974. Strategy, structures and economic performance. Boston: Harvard University, 2.

Steinbruner, J.D. 1974. The cybernetic theory of decision. Princeton: Princeton University Press.

Stewart, R. 1967. Managers and their jobs. London: Macmillan.

Stewart, R. 1979. The reality of management. Revised edition, London: Pan Books, 66-75.

Thompson, J.D. 1967. Organisation action. New York: McGraw-Hill.

\section{Appendix}

Programme for management development, $X X I$

Saturday's session was on the Theory of Management Style. As was stated, style could often be influenced by this environment and the perceptual orientations of a particular manager. In order to determine how the perceptions of managers on this course, with regard to certain managerial orientations differ, the following exercise is outlined. The results of this research will be discussed on Thursday.

1. Please rank all of the attached slips from the most closely-related orientations to the least-closely related orientations. The job orientations are defined below. So, for example, you may believe Political orientation to be closely related to Resource orientation but not at all related to Strategic orientation. The one would appear at the top and the other at the bottom of the pile of slips.

2. Method

In order to establish a rank order it is usually easier to start with three obvious classifications: 
(a) Those that are obviously related,

(b) those that are obviously not closely related, and

(c) those that fall between the two.

Then it is a matter of ranking within each classification.

3. Please have them in the collection box placed in the reception area by 08h30 tomorrow morning.

\section{Definitions}

1. Tasks involving target setting, e.g., goals of objectives, profit targets and planning, are defined as Strategic orientation.

2. Tasks involving the allocation of resources as determined by both functional and business needs, and maintaining a balance between the two, are defined as Resource orientation.

3. Problem identification and solving (fire-fighting) is defined as Problem orientation.

4. The job of getting corporate staff, other relevant departments or divisions, and important external groups to cooperate, despite lack of formal authority over them, is defined as Network orientation.

5. Motivating and controlling, sometimes a large and diverse group of subordinates, is defined as Subordinate orientation.

6. A job that focuses on a particular functional area such as marketing, production, finance, as opposed to 'General Management Areas', is defined as Functional orientation.

7. Being involved in the 'political' manoeuvers of the organization is defined as the Political orientation.

8. Being involved in establishing and maintaining the most suitable organization design for present and future strategies is defined as Structual orientation.

Please indicate your ranking of the combinations below: COMBINATION

01 STRATEGIC

RANKING

$\begin{array}{lll}02 & \text { STRATEGIC } & \text { - NETWORK } \\ 03 & \text { STRATEGIC } & \text { - SUBORDINATE } \\ 04 & \text { STRATEGIC } & \text { - FUNCTIONAL } \\ 05 & \text { STRATEGIC } & \text { - POLITICAL } \\ 06 & \text { STRATEGIC } & \text { - STRUCTURAL } \\ 07 & \text { STRATEGIC } & \text { - PROBLEM } \\ 08 & \text { RESOURCE } & \text { - NETWORK } \\ 09 & \text { RESOURCE } & \text { - SUBORDINATE } \\ 10 & \text { RESOURCE } & \text { - FUNCTIONAL } \\ 11 & \text { RESOURCE } & \text { - POLITICAL } \\ 12 & \text { RESOURCE } & \text { - STRUCTURAL } \\ 13 & \text { RESOURCE } & \text { - POLITICAL } \\ 14 & \text { NETWORK } & \text { - SUBORDINATE } \\ 15 & \text { NETWORK } & \text { - FUNCTIONAL } \\ 16 & \text { NETWORK } & \text { - POLITICAL } \\ 17 & \text { NETWORK } & \text { - STRUCTURAL } \\ 18 & \text { NETWORK } & \text { - PROBLEM } \\ 19 & \text { SUBORDINATE } & \text { - FUNCTIONAL } \\ 20 & \text { SUBORDINATE } & \text { - POLITICAL }\end{array}$

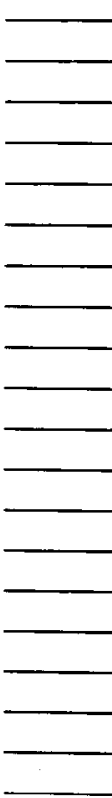

21 SUBORDINATE - STRUCTURAL

22 SUBORDINATE - PROBLEM

23 FUNCTIONAL - POLITICAL

24 FUNCTIONAL - STRUCTURAL

25 FUNCTIONAL - PROBLEM

26 POLITICAL - STRUCTURAL

27 POLITICAL - PROBLEM

28 STRUCTURAL - PROBLEM

Now complete this brief questionnaire.

(1). In your organization what level of management do you hold?

(Tick off that which is applicable).

Top

Middle

Lower

(2). Please rank the defined orientations according to the column headings shown below. (Rank 1 to 8 in order of preference, i.e. 1 is the most preferred.)

\begin{tabular}{|c|c|c|c|c|}
\hline & 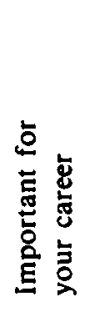 & 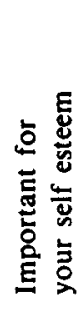 & 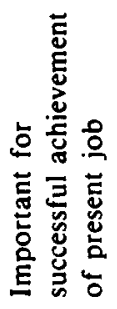 & 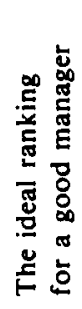 \\
\hline \multicolumn{5}{|l|}{$\begin{array}{l}\text { Strategic } \\
\quad \text { orientation }\end{array}$} \\
\hline \multicolumn{5}{|l|}{$\begin{array}{l}\text { Resource } \\
\text { orientation }\end{array}$} \\
\hline \multicolumn{5}{|l|}{$\begin{array}{l}\text { Network } \\
\text { orientation }\end{array}$} \\
\hline \multicolumn{5}{|l|}{$\begin{array}{l}\text { Subordinate } \\
\text { orientation }\end{array}$} \\
\hline \multicolumn{5}{|l|}{$\begin{array}{l}\text { Functional } \\
\text { orientation }\end{array}$} \\
\hline \multicolumn{5}{|l|}{$\begin{array}{l}\text { Political } \\
\text { orientation }\end{array}$} \\
\hline \multicolumn{5}{|l|}{$\begin{array}{l}\text { Structural } \\
\text { orientation }\end{array}$} \\
\hline $\begin{array}{l}\text { Problem } \\
\text { orientation }\end{array}$ & & & & \\
\hline
\end{tabular}

